\title{
Kajian Pengaruh Dua Metode Pemurnian Terhadap Kerjernihan dan Kadar Patchoul alcohol Minyak Nilam (Patchouly OIL) Asal Sumedang
}

\author{
Study on Effect of Two Purification Methods on Clarity and Patchouly Alcohol content of Patchouly \\ Oil from Sumedang \\ Sarifah Nurjanah"1), Sudaryanto Zain ${ }^{1)}$, S. Rosalinda ${ }^{1)}$ dan Ilham Fajri ${ }^{1)}$ \\ Departemen Teknik Pertanian dan Biosistem FTIP Universitas Padjadjaran \\ Jalan Raya Bandung-Sumedang Km 21, Jatinangor 40600 \\ Email : sarifah@unpad.ac.id
}

\begin{abstract}
ABSTRAK
Indonesia merupakan penghasil minyak nilam dunia yang paling tinggi, akan tetapi nilai jual minyak nilam terutama minyak nilam dari Sumedang mempunyai harga jual yang rendah. Hal ini disebabkan karena mutu terutama kejernihan dan kadar PA yang belum memenuhi preferensi konsumen. Penelitian ini bertujuan untuk mempelajari pengaruh pemurnian secara kimia dan secara fisik terhadap kejernihan dan kadar PA minyak nilam. Metode yang digunakan adalah metode eksperimental dengan analisis deskriptif. Pemurnian secara kimia dengan menggunakan asam sitrat ( $1 \%$ dan $2 \%)$, bentonit $(2,5 \%$ dan $5 \%$ ) dan campuraan asam sitrat $(1 \%)$ dengan natrium sitrat (1\% dan $2,5 \%$ ), sedangkan pemurnian secara fisik dilakukan dengan redestilasi. Percobaan dilakukan sebanyak tiga kali ulangan. Hasil penelitian menunjukkan bahwa proses pemurnian dapat meningkatkan mutu minyak nilam terutama kejernihan. Minyak nilam yang tadinya berwarna kuning buram ke coklatan menjadi menjadi kuning terang. Pemurnian minyak juga dapat meningkatkan kadar PA jika menggunakan metode redestilasi dan penggunaan asam sitrat dan natrium sitrat dari kadar PA 29\% menjadi 30\%.
\end{abstract}

Kata kunci : minyak nilam, pemurnian kimia, pemurnian fisik, kejernihan, kandungan PA

\section{ABSTRACT}

Indonesia is one of the largest patchouly oil production in the world, however selling price of patchouly oil particularly from Sumedang was low. This due to its clarity and PA content were not matched with consumer preferences. This study aimed to find out the effect of two purification methods on clarity and PA content of Patchouly Oil from Sumedang in order to produce pathouly oil that macth with consumer desires. Method used in this study was experiment with descriptive analysis (3 replication). Chemical purification used citric acid (1\% and $2 \%)$, bentonite $(2.5 \%$ and $5 \%)$, mixture of citric acid (1\%) and citric $\mathrm{Na}(1 \%$ and $2.5 \%)$. The result showed that purification process significantly increase clarity of the oil. Clarity of patchouly oil was showed by its color from brownish yellow became clear yellow. Purification was able to increase PA content for physical purification (redestilation). The PA content increased from $29 \%$ to $30 \%$.

Keywords: patchouly oil, chemical purification, physical purification, clarity, PA content

Diterima : 5 Juli 2016; Disetujui : 31 Agustus 2016 ; Online Published : 31 Oktober 2016

\section{PENDAHULUAN}

Dari berbagai jenis minyak atsiri yang ada di Indonesia, minyak nilamlah yang menjadi primadona, setiap tahunnya lebih dari
$45 \%$ devisa negara yang dihasilkan dari minyak atsiri berasal dari minyak atsiri berasal dari minyak nilam dan sekitar $85 \%$ kebutuhan minyak nilam dunia berasal dari Indonesia

24 Kajian Pengaruh Dua Metode Pemurnian Terhadap Kerjernihan dan Kadar Patchouli Alcohol Minyak Nilam (Patchouly Oil) Asal Sumedang 
(Santoso, 1991). Sentra produksi minyak nilam Indonesia adalah di daerah Aceh akan tetapi di daerah lain produksi minyak nilam juga sudah dikembangkan diantaranya adalah di Jawa Barat. Produksi nilam di Jawa Barat terutama di kembangkan di daerah Majalengka, Garut, Kuningan, Tasikmalaya dan Sumedang. Sumedang merupakan daerah potensi pengembangan produksi minyak nilam dengan luas potensi penanaman tanaman nilam 206 ha, yang tersebar di daerah Pamulihan, Rancakalong, Buah Dua, Pasanggrahan dan Narimbang, Congeang.

Minyak nilam yang dihasilkan oleh penyuling di Sumedang selama ini dijual pada tengkulak dengan harga yang rendah yaitu sekitar $\mathrm{Rp} 320.000,-/ \mathrm{kg}$. Dengan harga demikian maka nilai tambah yang diterima oleh petani tentulah masih rendah dibandingkan jika dijual pada pembeli luar negeri (Amerika Serikat dan Arab Saudi) yang dapat membeli sekitar $\$ 80 / \mathrm{kg}$. Akan tetapi penjualan ke luar negeri terkendala dengan mutu minyak nilam yang masih belum dapat memenuhi persyaratan yang diajukan oleh pembeli diantaranya kejernihan dan kandungan PA (patchouli alcohol) yang masih rendah. Untuk itu diperlukan teknologi tepat guna yang dapat meningkatkan kejernihan dan kandungan PA minyak nilam tersebut, dalam hal ini dapat dilakukan dengan mengaplikasikan proses pemurnian minyak nilam yang selama ini belum dilakukan di daerah tersebut. Pemurnian yang dilakukan haruslah mudah, tidak membutuhkan investasi yang besar dan ramah ligkungan.

Pemurnian merupakan proses penghilangan bahan-bahan yang tidak diinginkan dari minyak nilam hasil penyulingan. Proses ini bertujuan untuk meningkatkan kualitas minyak agar mempunyai nilai jual yang lebih tinggi. Metode pemurnian yang dikenal adalah pemurnian secara kimia dan fisik. Pemurnian secara kimia dapat dilakukan dengan menambahkan adsorben atau senyawa komplek tertentu. Peralatan yang digunakan dalam pemurnian ini cukup sederhana. Sedangkan pemurnian secara fisik memerlukan peralatan penunjang yang cukup spesifik, akan tetapi minyak yang dihasilkan lebih baik karena warnanya lebih jernih dan komponen utamanya menjadi lebih tinggi (Hernani dan Warwati, 2006).

Adsorpsi adalah proses difusi suatu komponen pada suatu permukaan atau antar partikel. Dalam adsorpsi terjadi proses pengikatan oleh permukaan adsorben padatan atau cairan terhadap adsorbat atom-atom, ionion atau molekul-molekul lainnya. Untuk proses tersebut bisa digunakan adsorben yang bersifat polar (silica, alumina, dan tanah diatome) ataupun non polar (arang aktif). Adsorbsi dapat juga menggunakan bentonit.

Pengkelatan adalah pengikatan logam dengan cara menambahkan senyawa pengkelat dan membentuk kompleks logam senyawa pengkelat. Proses pengkelat dilakukan dengan cara yang sama dengan adsorpsi hanya dengan mengganti adsorben dengan senyawa pengekelat. Senyawa pengkelat yang cukup dikenal dalam proses pemurnian minyak atsiri antara lain asan sitrat, asam malat, asan tartarat dan EDTA. Proses pengikatan logam merupakan proses keseimbangan pembentukan kompleks logam dengan senyawa pengkelat (Ketaren, 1985).

Pada proses secara fisik yaitu metode redestilasi adalah menyuling ulang minyak atsiri dengan menambahkan air pada perbandingan minyak dan air sekitar 1: 5 dalam labu destilasi, kemudian campuran didestilasi. Minyak yang dihasilkan akan terlihat lebih jernih. Hasil penelitian Purnamawati (2000) menunjukkan bahwa penyulingan ulang dengan metode redestilasi dapat meningkatkan nilai transmisi (kejernihan) dari 4\% menjadi 83,4\%.

Penelitian ini bertujuan untuk mengkaji beberapa metode pemurnian yang tepat guna, mudah diaplikasikan dan tidak membutuhkan biaya yang mahal serta ramah lingkungan. Diharapkan dengan penerapan metode tersebut akan dapat meningkatkan kejernihan dan kadar PA minyak nilam sehingga akan dapat meningkatkan nilai jual yang pada akhirnya dapat meningkatkan kesejahteraan petani dan penyuling minyak nilam.

\section{METODOLOGI PENELITIAN}

\section{Bahan dan Alat}

Bahan baku yang digunakan dalam penelitian ini adalah minyak nilam hasil 
penyulingan kelompok tani nilam, di Kabupaten Sumedang. Sedangkan bahan kimia yang digunakan untuk analisa mutu antara lain $\mathrm{KOH}, \mathrm{HCl}, \mathrm{HNO}_{3}$, indikator $\mathrm{pp}$, $\mathrm{NaCl}$ dan alkohol $90 \%$.

Alat-alat yang digunakan antara lain gelas ukur, piknometer, termometer, sokhlet apparatur, labu destilasi, reciever, kondensor, timbangan, pengaduk hotplate stirrer, corong, saringan, pipet, mantel heater, dan labu ukur.

\section{Metode}

\begin{tabular}{lcc}
\multicolumn{1}{c}{ Metode yang digunakan adalah } \\
eksperimental & dengan analisis & secara \\
deskriptif. & Pemurnian secara kimia
\end{tabular} menggunakan asam sitrat dengan konsentrasi $1 \%$ dan $2 \%$, bentonit $2,5 \%$ dan $5 \%$, campuran asam sitrat $1 \%$ dan natrium sitrat $1 \%$ dan 2,5\%. Sedangkan pemurnian secara fisik dengan redestilasi menggunakan alat destilasi secara kontinyu. Percobaan dilakukan sebanyak tiga kali ulangan. Hasil pemurnian kemudian dianalisa mutunya dengan melihat kejernihan, kandungan PA (Patchouli alcohol), berat jenis, bilangan asam dan bilangan ester.

\section{HASIL DAN PEMBAHASAN}

\section{Karakteristik Awal Bahan}

Bahan baku yang digunakan adalah minyak nilam yang berasal dari kelompok tani. Hasil analisis menunjukkan bahwa minyak tersebut mempunyai kandungan PA sebesar $29 \%$ dengan warna kuning buram kecoklatan (Gambar 1). Dengan kadar PA dan warna yang demikian harga minyak berkisar antara Rp 300.000,- sampai Rp 400.000,-. Hasil analisis terhadap beberapa parameter mutu disajikan pada Tabel 1.

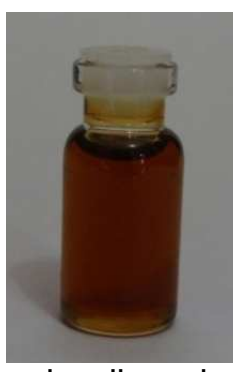

Gambar 1. Minyak nilam hasil penyulingan kelompok tani
Tabel 1 memperlihatkan bahwa jika mutu contoh dibandingkan dengan standar EOA dan SNI maka beberapa parameter mutu yaitu bobot jenis, bilangan asam dan bilangan ester masih memenuhi persyaratan kedua standar tersebut, akan tetapi apabila dilihat dari kadar PA dan warna maka minyak nilam hasil penyulingan kelompok tani masih di bawah standar yang disyaratkan.

Tabel 1. Karakteristik minyak nilam hasil penyulingan kelompok tani dan menurut standar EOA dan SNI.

\begin{tabular}{|c|c|c|c|}
\hline $\begin{array}{c}\text { Karakteri } \\
\text { stik }\end{array}$ & Contoh & EOA & SNI \\
\hline Fisik & $\begin{array}{l}\text { Kuning } \\
\text { buram } \\
\text { kecoklatan }\end{array}$ & $\begin{array}{c}\text { Cairan berwarna } \\
\text { coklat kehijauan } \\
\text { sampai coklat } \\
\text { tua, aromanya } \\
\text { khas dan sedikit } \\
\text { mirip kamper }\end{array}$ & $\begin{array}{l}\text { Warna kuning muda } \\
\text { sampai cokelat tua, } \\
\text { rekom endasi bau } \\
\text { segar, khas minyak } \\
\text { nilam }\end{array}$ \\
\hline $\begin{array}{l}\text { Bobot } \\
\text { Jenis }\end{array}$ & $\begin{array}{c}0,9550 \\
\left(\text { pada } 25^{\circ} \mathrm{C}\right)\end{array}$ & $\begin{array}{c}0,950-0,975 \\
\left(\text { pada } 25^{\circ} \mathrm{C}\right)\end{array}$ & $\begin{array}{l}0,943-0,983 \\
\left(\text { pada } 25^{\circ} \mathrm{C} \text { ) }\right.\end{array}$ \\
\hline $\begin{array}{l}\text { Bilangan } \\
\text { Asam }\end{array}$ & $1,63 \%$ & maksimum $5 \%$ & maksimum 5\% \\
\hline $\begin{array}{l}\text { Bilangan } \\
\text { Ester }\end{array}$ & $6,35 \%$ & maksimum $10 \%$ & Maksimum $10 \%$ \\
\hline Kadar PA & $29 \%$ & $>30 \%$ & $>30 \%$ \\
\hline
\end{tabular}

Padahal kedua sifat mutu tersebut yaitu kadar PA dan warna merupakan faktor penentu harga jual minyak nilam, sehingga harga jual minyak nilam hasil penyulingan kelompok tani masih tergolong rendah.

\section{Proses Pemurnian Minyak Nilam}

Proses pemurnian yang dikaji terdiri dari dua macam metode yaitu metode kimia dan secara fisik dengan cara redestilasi. Pemurnian secara kimia dilakukan dengan menggunakan bahan-bahan yang mudah didapat di pasaran dengan harga yang terjangkau oleh penyuling yaitu asam sitrat, bentonit dan natrium sitrat.

Pemurnian secara kimia dengan penambahan asam sitrat bertujuan untuk menghilangkan logam yang kemungkinan terikut dari proses penyulingan baik berasal dari bahan yang masuk maupun dari peralatan penyulingan. Logam yang tercampur pada minyak akan menyebabkan minyak menjadi berwarna gelap. Asam sitrat sebagai chelating

26 Kajian Pengaruh Dua Metode Pemurnian Terhadap Kerjernihan dan Kadar Patchouli Alcohol Minyak Nilam (Patchouly Oil) Asal Sumedang 
agent akan mengikat logam sehingga diharapkan dengan pengikatan logam oleh asam sitrat yang membentuk komplek logamsitrat akan dapat meningkatkan kejernihan minyak.

\section{a. Pemurnian secara kimia}

Penjernihan dengan menggunakan asam sitrat dilakukan dengan cara mencampurkan asam tersebut ke dalam minyak nilam sesuai perbandingan yang dicobakan yaitu $1 \%$ dan $2 \%$, kemudian campuran tersebut diaduk selama 15 menit pada suhu 50oC. Bahan kemudian disaring untuk memisahkan minyak dengan pengotornya.

Hasil analisis terhadap beberapa parameter mutu disajikan pada Tabel 2. Tabel 2 memperlihatkan bahwa jika mutu minyak sesudah dimurnikan dengan asam sitrat dibandingkan dengan minyak awal maka kejernihannya meningkat hal ini dapat dilihat dari perubahan warna yang terjadi dari kuning buram kecoklatan menjadi kuning terang. Akan tetapi meningkatnya kejernihan tidak diikuti dengan peningkatan kadar PA. Kadar PA tetap 29\% meskipun dimurnikan dengan asam sitrat tersebut. Hal ini disebabkan karena asam sitrat hanya merupakan chelating agent yang dapat mengikat logam saja sehingga hanya mempengaruhi perubahan warna pada minyak yang disebabkan oleh adanya logam.

Bobot jenis dan bilangan ester minyak nilam awal dan sesudah dimurnikan dengan asam sitrat $1 \%$ maupun $2 \%$ tidak menunjukkan perbedaan yang signifikan hal ini diduga karena sebagai chelating agent asam sitrat hanya mengikat logam dan tidak menghilangkan kotoran lainnya maupun merubah komponen ester sehingga nilai bobot jenis dan bilangan ester tidak berbeda. Nilai bilangan asam lebih tinggi pada penggunaan asam sitrat dan meningkat dengan meningkatnya konsentrasi asam sitrat yang digunakan. Hal ini diduga karena dengan menggunakan asam sitrat meskipun telah dilakukan pemisahan residu tetap masih ada assam sitrat yang terikut pada produk hasil pemurnian sehingga nilai bilangan asam meningkat.

Pemurnian secara kimia yang kedua dilakukan dengan mencampurkan bentonit. Pemurnian dengan bentonit bertujuan untuk menghilangkan warna gelap pada minyak yang disebabkan oleh terikutnya zat-zat warna selama penyulingan dengan cara adsorpsi oleh permukaan bentonit.
Tabel 2. Karakteristik minyak nilam hasil pemurnian dengan asam sitrat

\begin{tabular}{lcccc}
\hline $\begin{array}{l}\text { Karakteri } \\
\text { stik }\end{array}$ & $\begin{array}{c}\text { Bahan } \\
\text { awal }\end{array}$ & $\begin{array}{c}\text { Asam } \\
\text { sitrat 1\% }\end{array}$ & $\begin{array}{c}\text { Asam } \\
\text { sitrat 2\% }\end{array}$ & SNI \\
\hline Fisik & $\begin{array}{c}\text { Kuning } \\
\text { buram } \\
\text { kecoklatan }\end{array}$ & $\begin{array}{c}\text { Kuning } \\
\text { terang }\end{array}$ & $\begin{array}{c}\text { Kuning } \\
\text { terang }\end{array}$ & $\begin{array}{c}\text { Warna kuning } \\
\text { muda sampai } \\
\text { cokelat tua, } \\
\text { rekomendasi } \\
\text { bau segar, } \\
\text { khas minyak } \\
\text { nilam }\end{array}$ \\
$\begin{array}{l}\text { Bobot } \\
\text { Jenis } \\
\text { (g/ml) }\end{array}$ & 0,9550 & 0,9576 & 0,9551 & $\begin{array}{c}0,943-0,983 \\
\text { (pada 25 } 5^{\circ} \text { ) }\end{array}$ \\
$\begin{array}{l}\text { Bilangan } \\
\text { Asam (\%) }\end{array}$ & 1,63 & 2,33 & 2,82 & $\begin{array}{c}\text { maksimum } \\
\text { Bilangan }\end{array}$ \\
$\begin{array}{l}\text { Ester (\%) } \\
\text { Kadar PA } \\
\text { (\%) }\end{array}$ & 6,35 & 5,85 & 6,20 & Maksimum 10 \\
\hline
\end{tabular}

Pada proses tersebut terjadi pengikatan oleh permukaan absorben (bentonit) terhadap adsornat (zat warna).

Penjernihan dengan menggunakan bentonit dilakukan dengan menambahkan bentonit ke dalam minyak nilam sesuai dengan perbandingan $(2,5 \%$ dan $5 \%)$, kemudian diaduk selama 15 menit pada suhu 30 oC. Larutan kemudian disaring untuk memisahkan minyak dengan pengotornya.

Hasil analisis terhadap beberapa parameter mutu disajikan pada Tabel 3. Tabel 3 memperlihatkan bahwa jika mutu minyak sesudah dimurnikan dengan bentonit dibandingkan dengan minyak awal maka kejernihannya meningkat hal ini dapat dilihat dari perubahan warna yang terjadi dari kuning buram kecoklatan menjadi kuning terang. Sedangkan untuk kadar PA pada pemberian dengan bentonit $2,5 \%$ kadar PA meningkat menjadi $30 \%$ dan pada pemberian bentonit 5\% kadar PA justru tidak naik yaitu 29\%. Hal ini menunjukkan bahwa pemberian bentonit yang paling optimum adalah $2,5 \%$ selain dapat menjernihkan dan meningkatkan PA juga dari sisi ekonomis tentu semakin sedikit bahan yang digunakan akan semakin menguntungkan.

Penggunaan bentonit sebagai bahan untuk pemurnian tidak berpengaruh terhadap nilai bobot jenis, bilangan asam dan bilangan ester. Hal ini diduga karena bentonite hanya mengabsorbsi zat warna pada minyak nilam saja sehingga tidak merubah kandungan asam maupun ester minyak nilam. 
Tabel 3. Karakteristik minyak nilam hasil pemurnian dengan bentonit

\begin{tabular}{|c|c|c|c|c|}
\hline $\begin{array}{c}\text { Karakteri } \\
\text { stik }\end{array}$ & $\begin{array}{c}\text { Bahan } \\
\text { awal }\end{array}$ & $\begin{array}{c}\text { Bentonit } \\
2,5 \%\end{array}$ & $\begin{array}{c}\text { Bentonit } \\
5 \%\end{array}$ & SNI \\
\hline$\overline{\text { Fisik }}$ & $\begin{array}{c}\text { Kuning } \\
\text { buram } \\
\text { kecoklatan }\end{array}$ & $\begin{array}{l}\text { Kuning } \\
\text { terang }\end{array}$ & $\begin{array}{l}\text { Kuning } \\
\text { buram }\end{array}$ & $\begin{array}{c}\text { Warna kuning } \\
\text { muda sampai } \\
\text { cokelat tua, } \\
\text { rekomendasi } \\
\text { bau segar, } \\
\text { khas minyak } \\
\text { nilam }\end{array}$ \\
\hline $\begin{array}{l}\text { Bobot } \\
\text { Jenis } \\
(\mathrm{g} / \mathrm{ml})\end{array}$ & 0,9550 & 0,9522 & 0,9538 & $\begin{array}{l}0,943-0,983 \\
\left(\text { pada } 25^{\circ} \mathrm{C} \text { ) }\right.\end{array}$ \\
\hline $\begin{array}{l}\text { Bilangan } \\
\text { Asam (\%) }\end{array}$ & 1,63 & 3,48 & 1,57 & maksimum 5 \\
\hline $\begin{array}{l}\text { Bilangan } \\
\text { Ester (\%) }\end{array}$ & 6,35 & 8,41 & 5,52 & Maksimum 10 \\
\hline $\begin{array}{l}\text { Kadar PA } \\
(\%)\end{array}$ & 29 & 30 & 29 & $>30$ \\
\hline
\end{tabular}

Pemurnian juga dilakukan dengan memberikan perlakuan kombinasi antara asam sitrat dengan natrium sitrat. Pemberian kedua bahan ini bertujuan untuk penghilangan logam dengan asam sitrat dan penyerapan partikel air dengan natrium sulfat. Pemurnian dengan memberikan bahan-bahan tersebut dilakukan secara bertahap. Pada tahap pertama minyak dimurnikan dengan asam sitrat $1 \%$, didinginkan dan sesudah dingin kemudian dimurnikan dengan menggunakan natrium sulfat sebanyak $1 \%$ dan $2,5 \%$.

Hasil analisis terhadap beberapa parameter mutu disajikan pada Tabel 4 . Tabel 4 menunjukkan bahwa pemurnian dengan asam sitrat dan natrium sitrat dapat meningkatkan kejernihan maupun kadar PA. Sesudah dimurnikan warna minyak menjadi kuning terang dan kandungan PA meningkat menjadi $30 \%$. Hal ini membuktikan bahwa dengan asam sitrat logam yang terdapat pada minyak dapat diikat dan dihilangkan sehingga warnanya menjadi jernih, serta natrium sitrat dapat mengikat air sehingga meningkatkan kadar PA minyak.

Penambahan asam sitrat dan natrium nitrat tidak berpengaruh terhadap bibit jenis, bilangan asam dan bilangan ester. Hal ini diduga karena sebagai chelating agent asam sitrat hanya mengikat logam dan tidak menghilangkan kotoran lainnya maupun merubah komponen ester sehingga nilai bobot jenis, bilangan asam dan bilangan ester tidak berbeda. Meskipun ditambahkan asam sitrat, bilangan asam minyak tidak berubah secara signifikan, hal ini diduga karena adanya penambahan natrium sitrat yang dapat menetralkan asam sitrat yang ditambahkan.

Tabel 4. Karakteristik minyak nilam hasil pemurnian dengan asam sitrat dan natrium sitrat

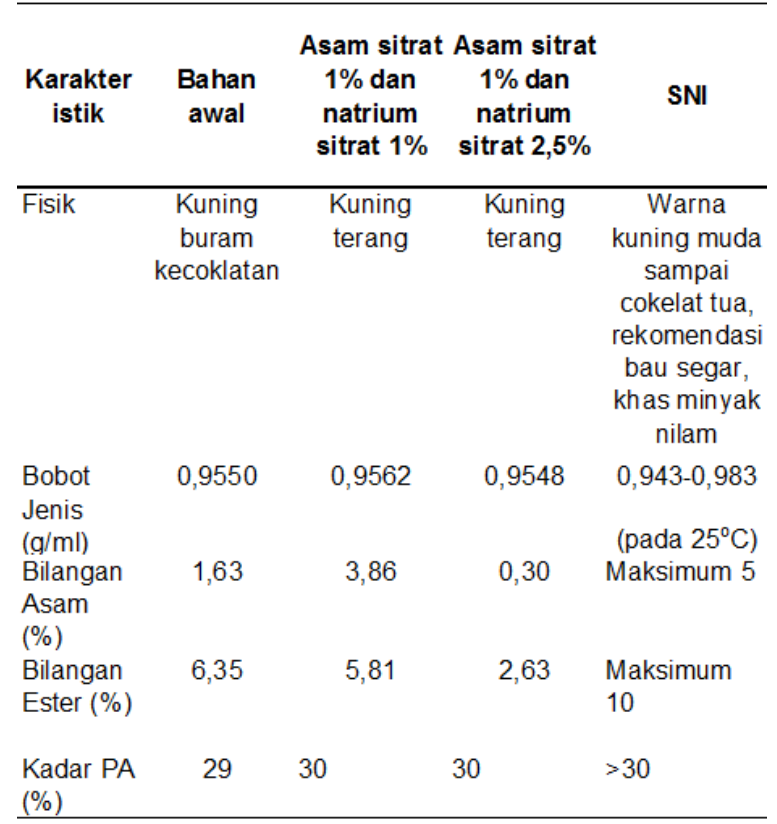

\section{b. Pemurnian secara fisik}

Pemurnian secara fisik dilakukan dengan redestilasi minyak hasil penyulingan kelompok tani. Proses destilasi dilakukan dengan menggunakan proses secara kontinyu. Minyak dicampur dengan air dengan perbandingan 1: 5 dan didestilasi pada suhu $160^{\circ} \mathrm{C}$. Proses destilasi disajikan pada Gambar 2.

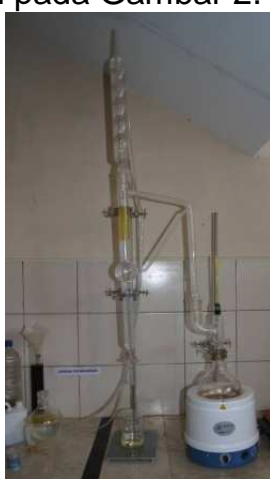

Gambar 2. Proses pemurnian secara fisik (redestilasi)

Pada proses pemurnian dengan metode ini selama destilasi minyak akan terpisah pada labu

28 Kajian Pengaruh Dua Metode Pemurnian Terhadap Kerjernihan dan Kadar Patchouli Alcohol Minyak Nilam (Patchouly Oil) Asal Sumedang 
penampung, setelah semua minyak terdestilasi kembali maka minyak dan air yang tercampur dipisahkan dan dianalisis mutunya. Minyak hasil pemurnian dengan metode ini disajikan pada Gambar 3, sedangkan hasil analisis mutu disajikan pada Tabel 5.

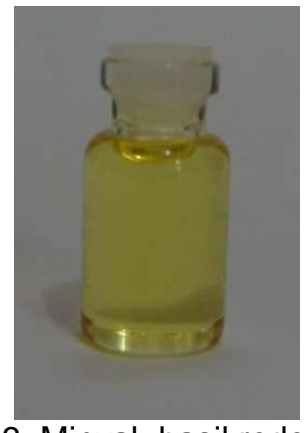

Gambar 3. Minyak hasil redestilasi

Tabel 5. Karakteristik minyak nilam hasil pemurnian secara fisik

\begin{tabular}{|c|c|c|c|}
\hline $\begin{array}{c}\text { Karakterist } \\
\text { ik }\end{array}$ & $\begin{array}{c}\text { Bahan } \\
\text { awal }\end{array}$ & $\begin{array}{c}\text { Minyak } \\
\text { redestilasi }\end{array}$ & SNI \\
\hline$\overline{\text { Fisik }}$ & $\begin{array}{c}\text { Kuning } \\
\text { buram } \\
\text { kecoklatan }\end{array}$ & $\begin{array}{l}\text { Kuning } \\
\text { terang }\end{array}$ & $\begin{array}{c}\text { Warna kuning muda } \\
\text { sampai cokelat tua, } \\
\text { rekomendasi bau } \\
\text { segar, khas minyak } \\
\text { nilam }\end{array}$ \\
\hline $\begin{array}{l}\text { Bobot Jenis } \\
(\mathrm{g} / \mathrm{ml})\end{array}$ & 0,9550 & 0,9399 & $\begin{array}{r}0,943-0,983 \\
\left(\text { pada } 25^{\circ} \mathrm{C}\right)\end{array}$ \\
\hline $\begin{array}{l}\text { Bilangan } \\
\text { Asam (\%) }\end{array}$ & 1,63 & 0,30 & maksimum 5 \\
\hline $\begin{array}{l}\text { Bilangan } \\
\text { Ester (\%) }\end{array}$ & 6,35 & 2,63 & Maksimum 10 \\
\hline $\begin{array}{l}\text { Kadar PA } \\
(\%)\end{array}$ & 29 & 31 & $>30$ \\
\hline
\end{tabular}

Hasil analisis menunjukkan bahwa selain dapat meningkatkan kejernihan warna, kandungan PA pun menjadi meningkat dengan pemurnian secara fisik ini. Gambar 3 memperlihatkan bahwa dibandingkan dengan pemurnian secara kimia maka tingkat kejernihan warna minyak jauh di atas hasil minyak setelah dimurnikan secara kimia. Hal ini disebabkan pada saat redestilasi maka yang menguap sebagian besar adalah komponen minyak sedangkan bahan-bahan penyebab warna gelap dan coklat seperti logam dan zat warna dari bahan tidak ikut teruapkan karena titik didihnya yang tinggi. Kandungan PA yang meningkat diduga karena bahan yang terdestilasi hanyalah komponen asli minyak sedangkan komponen lainnya tidak terikut sehingga kadar PA juga meningkat. Selain itu nilai bobot jenis, bilangan asam dan bilangan ester menjadi turun. Bobot jenis selain menunjukkan berat komponen di dalam bahan juga dapat memperlihatkan tingkat kemurnian bahan (Guenther, 1987). Adanya penurunan bobot jenis diduga disebabkan karena hasil destilasi merupakan minyak nilam murni tanpa pengotor yang tidak dapat ikut menguap selama proses redestilasi, sehingga menurunkan bobot jenisnya. Bilangan asam dan bilangan ester yang turun diduga karena kondisi suhu dan tekanan proses redestilasi

Dengan adanya peningkatan mutu ini maka diharapkan apabila pemurnian dengan cara ini dilakukan oleh kelompok tani maka akan dapat memenuhi standar baik SNI maupun EOA, sehingga jarga jualnya akan naik dan pada akhirnya akan dapat meningkatkan kesejahteraan petani.

\section{KESIMPULAN}

Hasil pengkajian proses pemurnian minyak nilam hasil penyulingan kelompok tani menunjukkan bahwa proses pemurnian dapat meningkatkan mutu minyak nilam terutama kejernihan, warna miyak awal yaitu kuning kecoklatan menjadi kuning jernih. Pemurnian minyak juga dapat meningkatkan kadar PA jika menggunakan metode redestilasi dan penggunaan asam sitrat dan natrium sitrat, dengan nilai awal $29 \%$ menjadi $30 \%$ dan $31 \%$.

\section{DAFTAR PUSTAKA}

Guenther, E. 1987. Minyak Atsiri jilid I (terjemahan). Ketaren, S. Penerbit Universitas Indonesia, Jakarta.

Hernani dan Marwati, T. 2006. Peningkatan Mutu Minyak Nilam melalui Proses Pemurnian. Disampaikan pada Konferensi Nasional Minyak Atsiri 2006, Solo 18_20 Sepetember 2006.

Ketaren, S. 1985. Pengantar Teknologi Minyak Atsiri. PN Balai Pustaka, Jakarta.

Purnamawati, R. 2000. Pemucatan Minyak Nilam dengan Cara Redestilasi dan Cara Kimia. Skripsi. Fateta, IPB Bogor. 